\title{
Joint Tenancy, Taxwise and Otherwise
}

\section{Arthur K. Marshall*}

TOINT TENANCX, a method of holding title to property once very much in vogue among the feudal barons, ${ }^{1}$ is enjoying even greater popularity today among all classes. ${ }^{2}$ In ancient times its great advantage was that it evaded the barons' creditors and held together vast estates. Today its appeal lies in the avoidance of the probate court with its attendant expense. Hundreds of surviving joint tenants have so informed the writer in his capacity as attorney for the State Inheritance Tax Department. In addition, the lay public labors under the delusion that joint tenancy, of which it has been apprised by the neighborhood notary or escrow clerk, can save taxes. Finally, many laymen believe that joint tenancy is the answer to all testamentary problems. All too many are later sadly disabused of such ideas.

At the outset let us recognize that joint tenancy is a convenient and inexpensive method of property disposition. It does offer procedural simplicity and does avoid some expense in many cases. It does get the title "passed" just as effectively as does a decree of distribution issued by a probate court. In fact the title has been transferred long before the death of one of the joint tenants, having "passed" when the joint tenancy was created. ${ }^{3}$ Such title is subject only to a cloud or encumbrance created by the existence of the other co-tenant, and upon his death, the survivor emerges as sole title holder. ${ }^{4}$ Only the death need be established, no more. More technically, it is sometimes said that each tenant acquired a specialized form of a life estate with what amounts to a remainder in the fee, contingent on survival. ${ }^{5}$

The high public opinion of this means of conveyance was amply demonstrated by the uproar over the attempt by the California Legislature in 1951 to make mandatory a court proceeding to terminate a joint tenancy. ${ }^{6} \mathrm{~A}$ form of conveyance standing in such high regard should be carefully analyzed before being condemned. ${ }^{7}$

Let us consider what is transferred before examining the consequences

* Member of Bars of California and New York; Assistant Inheritance Tax Attorney for the State of California. The views expressed in this article are not necessarily those of the Inheritance Tax Department.

148 C.J.S. 910 (1947); Thompson, ReaI Property $\$ 1778$ (Perm. ed., 1712); Co. Inst. 182a-188a (1809) (of Joint Tenants).

$2 \mathrm{Mr}$. Melvin B. Ogden, Chief Title Officer, Title Insurance and Trust Company, has informed the writer that title records indicate that $85 \%$ of all real property acquisitions by husband and wife are in joint tenancy.

3 Green v. Skinner, 185 Cal. 435, 197 Pac. 60 (1921).

4 Plante v. Gray, 68 Cal. App. 2d 582, 157 P.2d 421 (1945).

$\checkmark$ Zeigler v. Bonnell, 52 Cal. App. 2d 217, 126 P.2d 118 (1942).

6 CAI. Prob. Code $\$ 1170$ as amended by Cal. Stats. 1951, c. 779, repealed by special session of 1952 legislature.

7 It is to be noted that despite its popularity, joint tenancy has been modified and restricted in many jurisdictions. 48 C.J.S. 912 (1947); 33 C.J. 901 (1924); 14 AMr. JUk. 84 (1938). Washington (REv. STat. $\$ 1344,1951$ ) has abolished the right of survivorship: Louisiana (REv. STaT., 1950) does not recognize joint tenancy. 
of the transfer. John Brown purchases a home and remarks to the escrow clerk or notary (very rarely to a lawyer): "Mary should have the house in case something happens to me." The escrow clerk or notary has on hand conveyance forms available for ten cents apiece. Only a few words need be typed thereon and it is done-Mary will have the house. As the years pass, a few bonds are placed in the name of "John or Mary"; a bank account is also labelled with the same magic words.

Up to this point, be it noted, John Brown's estate rarely exceeds the federal estate and state inheritance tax exemptions, so the parties need not concern themselves with the tax consequences attendant on the death of either spouse. Usually John operates under the firm conviction that his tax immunity is due to the form signed years before. Suffice it to say at this point that the capital gains tax which may accrue by the operation of Section 113(a) (5), Internal Revenue Code, is usually unknown to John, and even where he is aware of its existence the consequences of its application seein too remote or too small to arouse any apprehension. The gift tax exemptions, which will also be discussed in greater detail later, generally prevent imposition of that tax where the assets consist of the small home, a few bonds and the usual minimal bank account.

Therefore, if we do not concern ourselves with the layman's attempt to use joint tenancy as a substitute for a will, and if we ignore the deleterious effects of Section 113(a) (5), it is evident that if the estate, including what is transferred into joint tenancy, does not exceed a valuation of $\$ 48,000$ at the date of death of the husband, ${ }^{9}$ the disadvantages of such transfer are too obscure, too remote or too slight to counterbalance its very real advantages. Hence its great and increasing popularity.

But let us go a short step further, and consider the John Brown whose home has an inflated value of $\$ 20,000$, whose car would be appraised at $\$ 1500$ were he to die today, whose bank account exceeds $\$ 2000$, who has managed to hold on to his war savings bonds totalling, say, $\$ 2000$ at maturity, and who may be slowly adding thereto. When he departs this life a few decades hence, it is obvious that his thrift and industry may very well have brought his total estate up to more than $\$ 48,000$. For the surprisingly large number of John Browns who fall into this category, the use of joint tenancy is not, in the opinion of this writer, to be recommended. In fact, its use could not only jeopardize all of John's plans for his widow and children after his demise but might also so reduce his assets under the combined onslaught of federal and state gift, estate, inheritance and income taxes as to leave little for his family.

\section{Gift Taxes}

If John Brown owned property prior to marriage or if he acquired property by "gift, devise, bequest, or descent" it is his separate property. ${ }^{10}$ Were

\footnotetext{
8 By permitting joint tenancy in the case of war bonds, the federal government has further popularized such conveyances.

9 Cat. Rev. \& TaX Code $\$ 13951$.

10 Cal. Crv. Code $\S 163$.
} 
he to convey such property into joint tenancy with Mary Brown, his spouse, he would be making a gift to her under both federal and state law, of onehalf of the value of the property. ${ }^{11}$ John has a lifetime exemption, for federal purposes, of $\$ 30,000 .^{12} \mathrm{He}$ also has an annual exemption, for each donee, of $\$ 3000 .^{13}$ If his property has a tax basis of $\$ 150,000$, the gift to Mary, one-half of the property, is $\$ 75,000 .{ }^{14}$ Mary is also entitled to a marital deduction of one-half, ${ }^{15}$ since April 2, 1948, when the Revenue Act of 1948 went into effect. Hence $\$ 37,500$ remains. Even if the entire specific exemption and the annual exemption are exhausted, a total of $\$ 33,000$, Mary has still received a taxable gift of $\$ 4500$.

Califorina treats the question of exemptions differently, basing them on relationship. Mary, for example, has an exeinption of $\$ 24,000,{ }^{16}$ John$\$ 5000,{ }^{17}$ a son- $\$ 12,000$ if a minor, $\$ 5000$ if adult, ${ }^{18}$ etc. Each donee also has an annual exemption of $\$ 4000 .^{19}$ Mary has, however, no "marital deduction" as to gifts of separate property. Therefore, after exhausting the specific exemption and the annual exemption, a total of $\$ 28,000$, it is apparent that, as to separate property, Mary is more vulnerable to state gift tax than to federal gift tax. Her taxable gift is one-half of the property, $\$ 75,000$, less $\$ 28,000$, or $\$ 47,000$. The value of the separate property transferred into joint tenancy must be scaled down to $\$ 56,000$ before Mary will avoid all state gift tax. If John places his separate property in joint tenancy with an adult son, the state gift tax is incurred if the property has a value over $\$ 18,000$. The specific exemptions being exhausted, the next outright gift made by John of his separate property to Mary, say, the following year, may not be more than $\$ 4000$, if taxes are to be avoided. If it is property in joint tenancy, its value must not exceed $\$ 8000$. The son's specific exemption having been consumed, he too cannot receive an outright gift of more than $\$ 4000$ or a gift in joint tenancy of more than $\$ 8000$ without tax. ${ }^{20}$

At this point it is relevant to emphasize that the California State gift and inheritance tax rates are extremely low: $2 \%$ for the first $\$ 25,000,3 \%$ for the next $\$ 25,000,4 \%$ for an additional $\$ 50,000$. Therefore, even though a gift or an inheritance is taxed by the state, the tax is ordinarily of slight consequeuce. The look of relief on the faces of prospective taxpayers who have just been informed of this aspect of the California state tax is pleasant to behold. While the writer has often enjoyed making an explanation of our low tax rates, his small pleasure is not shared by his counterpart among the

\footnotetext{
11 U. S. Treas. Reg. 108, § 86.2 (1952) ; CaL. Admin. Code Tit. 18, § 61.

12 INT. REv. CODE $\$ 1004$ (a) (1).

13 Int. Rev. CODE $\$ 1003$ (b) (3).

14 U.S. TREas. REg. 108, $\$ 86.2$ (1952).

15 U.S. Treas. REg. 108, § 86.16A (1952).

10 CaL. Rev. \& Tax Code $§ 15421$.

17 Ibid.

18 Ibid.

10 Cal. Rev. \& Tax Code $\$ 15401$.

20 The state gift tax scale is exactly the same as the state inheritance tax rates. Gift taxes paid may be taken as a credit, albeit only partial, against any inheritance tax on the same
} property. 
federal authorities, judging by the rate schedule contained in Section 1001, Internal Revenue Code.

Let us assume that John and Mary have been married for a number of years and that his earnings during marriage with Mary but prior to July 29 , $1927,{ }^{21}$ were used to purchase and place in joint tenancy property worth $\$ 150,000$. He will still owe the saine gift tax to the federal government, ${ }^{22}$ as if the property so employed had been his separate property. ${ }^{23}$

Statewise, there is no taxable gift where community property is used, since for gift tax purposes, California treats old community property the same as new, and therefore considers Mary to have acquired no more than she had before the transfer into joint tenancy. ${ }^{24}$

If the joint tenancy were created out of $\$ 150,000$ of "new" community property-funds earned in wedlock after July 29, 1927-it would appear that the federal government could not collect any gift tax ${ }^{25}$ No state tax would be due for the reason given in the preceding paragraph.

The bramblebush of joint tenancy can be perceived, at the outset of our inquiry, to be rather thorny. The average joint tenant rarely knows that there is a bramblebush, and he is entirely ignorant of the tax distinctions drawn between separate property and old and new community property. The fact that he can incur a gift tax, however small, by placing as little as $\$ 56,000$ of his separate property in joint tenancy with his wife, that subsequent gifts into joint tenancy in later years which exceed $\$ 3000$ federally and $\$ 4000$ statewise inay be taxable, and that interest on the unpaid taxes will accrue as a result of his failure to file gift tax returns are all unknown consequences of joint tenancy.

\section{Estate and Inheritance Taxes and Proceedings on Death}

Where the property is conveyed outright rather than in joint tenancy and where the transfer would not be considered as one made in contemplation of death, the transferred property would not be subject to state or federal death taxes when the transferor dies. However, if the property is transferred into joint tenancy and the transferor dies, the entire property is subject to federal estate ${ }^{26}$ and state inheritance taxes, ${ }^{2 \tau}$ in addition to the

21 Effective date of Car. Civ. Code $\$ 161 a$.

${ }^{22}$ Horst v. Commissioner, 150 F.2d 1 (9th Cir. 1945), cert. denied, 326 U.S. 761 (1945). Prior to 1927, a wife had a "mere expectancy" in commumity property.

23 It is termed "old" community property.

24 Car. REv. \& TAX CoDE $\$ \S 15301,15304$.

25 INT. REv. CODE $\$ 1000$ (d) declares husband's gifts of community property after 1942 and prior to 1948 are entirely taxable. But see Edward M. Mills, 12 T.C. 468, aff'd. 183 F.2d 32 (9th. Cir. 1950), in which the court held that a division of community earnings was not a taxable gift to the wife, though earned during the period 1943-1945.

26 INT. REv. CoDE § 15301. In Estate of Don Murillo Brockway, 18 T.C. No. 58 (1952), spouses purchased property with new community funds and placed it in joint tenancy. Shortly before the husband's death they conveyed the property to their children, a conveyance held to be in contemplation of death. However, as the widow's community interest paid for half of the property and she was still alive, only half was held includible in the husband's estate. Had the transfer not been in contemplation of death, the entire amount would have been free of inheritance and estate taxes. If the property had remained in joint tenancy half (leaving aside the three-fourths, one-fourth theory for the moment) would have been taxable regardless of the circumstances under which the spouses entered into joint tenancy.

27 Cal. Rev. \& Tax CODE § 13671 . 
gift taxes. No matter how many years elapse between the creation of the joint tenancy and death, the property still remains subject to death taxes.

Upon the death of a joint tenant the entire property is included in his taxable estate. ${ }^{28}$ Both federal estate and California inheritance taxes are computed on the basis of the whole joint tenancy property together with the "probate" property. This elementary proposition is unknown to nine out of ten of the laymen, who have not consulted an attorney, and whom the writer has interviewed in the course of his duties at the State Inheritance Tax Department. They had all been told by "everyone," except a lawyer, that placement in joint tenancy ended all death tax problems. The California Supreme Court, ${ }^{29}$ summing up the evidence presented in a very recent case, informs us that: "Deceased's stockbroker testified that in 1946 deceased began to talk to him about saving inheritance taxes; that he then "pointed out the advantages of a joint tenancy'; . . . "Such "advice" cost the decedent nothing and, as usual, was worth less than nothing.

Under both the federal law and that of California, the surviving joint tenant who can prove that all or part of the joint tenancy property was originally his property or that he paid the decedent full and adequate consideration for it can obtain the exclusion of the part he contributed or purchased. ${ }^{30}$

For exainple, if from their individual separate property Mary and John each contributed $50 \%$ of the cost of an asset worth $\$ 10,000$, at the death of John, one-half of the $\$ 10,000$, or $\$ 5000$, is Mary's contribution and may be deducted before considering the marital exemption. If Mary had paid $25 \%$ of the cost, her deduction would be $\$ 2500$.

When one turns to the task of production of proof, the illusory nature of benefits from these provisions becomes apparent. The joint tenancy was created, more likely than not, many years before the death, and no record was kept which would show how inuch each joint tenant contributed.

"The decisions on the point establish that in the majority of estate the executor is helpless because of the absence of convincing proof [of contribution]." 31 Further, both joint tenants may die in a common disaster, leaving no one capable of proving contribution. The writer has observed attorneys struggling for months on end (and often for nominal fees), to find and put together the bits of evidence carelessly scattered or destroyed by the joint tenants. ${ }^{32}$ The incidence of failure is very high because of the general carelessness with records. As the surviving joint tenant who can prove his or her contribution is a rare find indeed, ${ }^{33}$ a survivor may very well have

28 Int. Rev. Code § 811 (e); Car. Rev. \& TaX Code § 13671.

29 Solon v. Iichtenstein, 39 A.C. $77,80,244$ P.2d 907, 909 (1952).

30 INT. Rev. Code $\$ 811$ (e); CAL. Rev. \& TAX CODE § 13671; U.S. TREAs. REg. 105, § 81.22 (1949); CAI. AdMIN CODE tit. $18, \S 674$.

31 Sinclaire, Taxation of Property Held Jointly and Estates by the Entirety, RECENT DEcisions and TaX Trends Supplenent (1952).

32 While the attorney's fee charged may be low relative to the tremendous amount of work involved in digging out the evidence and fending off various false claims, the survivors still have lost the advantage of no attorney fees supposed to result from joint tenancy.

33 One of those rare cases was Harvey v. U.S., 185 F.2d 463 (7th Cir. 1950). 
contributed the entire cost of the property but still be helpless, for lack of proof, to prevent the property from being taxed in toto as that of the decedent, and a second time at his own death.

Assume that proof of contribution is available and suppose that husband John dies first, as he does in two out of three marriages. ${ }^{34}$ If the property was originally John's separate property, Mary pays the same tax which would be due if the property were held in his name only and willed to Mary. If it was the separate property of Mary, she would owe no tax upon John's death if she can prove it. Frequently she cannot.

If we assume instead that Mary succumbs first, under the joint tenancy sections of the federal and California tax law the entire property is considered her separate property, subject to proof of contribution by John. ${ }^{35} \mathrm{We}$ nuust look to the origin of this property for such proof. ${ }^{36}$ If it was bought with "new" (post 1927) community funds, half of such funds constitute John's community interest. ${ }^{3 T}$ Hence, if it can be shown that community funds were used to buy the property, John would be entitled to a $50 \%$ deduction for his contribution. John can also secure a further reduction of tax by means of the federal marital deduction ${ }^{38}$ and the state marital exemption. ${ }^{39}$ These "niaritals" grant an exemption from tax of all the separate property the surviving spouse takes, up to $50 \%$ of the total gross adjusted estate. John is, therefore, entitled to an exemption of one-half of the remaining half of the separate property. His exemptions total $75 \%$, and only one-fourth of the property is taxed. But, had the property been purchased in the names of John and Mary Brown as husband and wife, ${ }^{40}$ or in John's name only, it would be all considered as community property and, statewise, be entirely exempt from tax. ${ }^{41}$

If the transfer into joint tenancy occurred prior to 1942 or during the period from January 1, 1943 to December $31,1947,{ }^{42}$ the federal authorities would be required to grant a $75 \%$ exemption in view of the Siberell $l^{43}$ case

34 Dubin, THe FACTS OF LIFE FROM BIRTH to DEATH, 53 (1951).

35 Int. Rev. Code § 811(e); CaI. Rev. \& TAX Code § 13671.

36 United States v. Jacobs, 306 U.S. 363 (1939).

3T CAL. CTV. Code $\$ 161 a$.

38 INT. REV. CODE $\$ 812$ (e).

39 Cac. Rev. \& Tax Code $\S 13805$.

40 Cat. Civ. Code $\$ 164$.

41 Cat. Rev. \& Tax CoDe $\S 13553$.

42 INT. REV. CODE $\$ 812$ (e)(2) (c) (ii) did not permit community property to be converted into separate property during the calendar year of 1942 and after January 1, 1948. If the husband died during the period from October 21, 1942, to January 1, 1948, the entire joint tenancy would be taxable in his estate, even though he and his wife had paid for joint tenancy property with post-1927 funds. Steen v. United States, 195 F.2d 379 (1952). A later death subjects joint tenancy property to more generous legislation, 44 Stat. 71 (1926), as amended, 62 STAT. 116 (1948), 26 U.S.C. $\$ 811$ (e) (Supp. 1951). Three-fourths may he free of tax if the death occurred subsequent to January 1,1948 , and a transfer into joint tenancy transpired prior to that date.

43 Siberell v. Siberell, 214 Cal. 767, 7 P.2d 1003 (1932), 5 So. Calrf. L. Rev. 344 (1932). See also Estate of Frary, 26 Cal. App. 2 d 83, 78 P.2d 760 (1938). In the Siberell case, a divorce proceeding, the wife claimed that half the property in joint tenancy was her separate property, and the other half was community property, half of which should be distributed to her. Mr. Justice Preston rejected the argument, declaring that a community estate and a joint tenancy cannot exist at the same time in the same property because of conflicting characteristics, and that the spouses had equal, scparate but joint estates in the property. 
and United States v. Jacobs. ${ }^{44}$ However, numerous attorneys have informed the writer that the Bureau has refused to so construe the law. In other words, the federal government will exclude $50 \%$ of the joint tenancy property as the commumity interest of the survivor just as it would if the property were held as commumity. Hence, joint tenancy secures no practical advantage under federal law, while under state law a quarter of the property is taxed which would not have been taxed had the joint tenancy not been created. Parenthetically, even if the Bureau did acquiesce in the line of reasoning just delineated, any prospective joint tenants would gain nothing thereby, for after April 2, 1948, such transmutation is no longer possible. Current federal law considers commumity property incapable of conversion into separate property after the effective date of the Revenue Act of 1948, April 2, 1948, as well as during 1942. However, it is also to be noted that the Bureau considers that transfers into joint tenancy of property bought with funds earned prior to July 29, 1927, the effective date of Section $161 \mathrm{a}$ of the Civil Code, involve only separate property of the husband. Thus, should the wife die first, there would be a $100 \%$ exemption because of $100 \%$ contribution.

California would also grant a full exemption to joint property originating in "old" commumity property, as Civil Code Section 161a did not deprive the husband of his full ownership until 1927. No advantage is gained over ordimary community property, however, as he would not be taxed on such commumity property anyway, should he survive.

If John dies first and if a true joint tenancy ${ }^{45}$ had been created out of new community property, Mary gains a three-fourths exemption consisting of one-half contribution, her half of the community having paid for half the jomt property, and half of the remaining half, or one-fourth of the whole, as a marital exemption. Were the property "new" community and not in joint tenancy, only $50 \%$ of the property would be excluded. Here it would appear that we have the rare situation of an advantage accruing from joint tenancy both in the view of the federal and state authorities. The advantage, however, insofar as the Bureau is concerned, is theoretical only. First, as stated in the discussion of Mary predeceasing John, the Bureau simply ignores the three-quarter exemption even though the transfer occurred during the periods in which the code pernitted such conversion. Secondly, the advantage vanished with the advent of the Revenue Act of 1948 and can no longer be granted. Thirdly, the spouses would be gambling on the earlier death of the husband, and statistics tell us that that gamble would be lost at least one time out of three. ${ }^{46}$ The prior death of the wife subjects one-fourth of the property to state inheritance tax which would not have been so taxed had joint tenancy been avoided. Fourthly, a "true" joint ten-

44 Supra note 36 .

45 "True joint tenancy" exists where the parties intended and agreed to convert community into separate property in joint tenancy. Siberell v. Siberell, supra note 43 . CAL. Adnorn. CodE $\$ 673 a$, rescinded August 7,1952 , treated joint tenancy property as community if its origin was community.

40 Dublin, supra note 34. 
ancy may not have been intended by Mary and John. Convincing proof may be forthcoming to show that the spouses had agreed that it was community property or that they did not have the slightest intention to give up their community property status and actually did not realize that they were doing so by entering into a joint tenancy. If such proof is furnished, possibly by the taxing authorities in whose interest it would be, both federal ${ }^{47}$ and state courts ${ }^{48}$ have ruled that the property remains community property even though the record title is in joint tenancy. The one advantage of an additional quarter exemption would be immediately wiped out.

While the Bureau may not be persuaded that a three-fourths exemption should be granted, the State Inheritance Tax Department may believe that the evidence supports such claim of the surviving joint tenant. The department deducts froin the gross estate a federal estate tax credit in computing the state tax. In conputing the federal estate tax, the state must consider the three-quarter exemption to have been granted by the Bureau if it, the state, is satisfied with the proof of compliance with federal law on the point. The resulting federal estate tax credit may be substantially less than the tax actually exacted by the federal government if the latter persists in its refusal to recognize the three-quarter exemption. Hence, Mary would not receive credit for the entire federal tax paid. In view of the facts, the writer believes that the slim possibility of obtaining a three-fourths exemption through joint tenancy is not worth the probable consequence of additional tax. In other words, while it is extremely doubtful that Mary will gain an additional fourth federal exemption if John dies first, it is virtually certain that John will lose a fourth of his state exemption if Mary dies first:

At this point a discussion of the Tomaier ${ }^{49}$ and Pierotti ${ }^{50}$ cases should be undertaken. In Tomaier, as in the Siberell case, a divorce decree was rendered on the ground of extreme cruelty. The trial court found that joint tenancy property was really community property and awarded a "substantial" part of it to the husband. The District Court of Appeal reversed that part of the judgment dividing the property as community. On retrial the husband attempted to introduce evidence that the joint tenancy property remained a part of the community. The denial of the admissibility of such evidence was appealed. Mr. Justice Traynor, a foremost tax authority on the bench, stated: "51 "It is the general rule that evidence may be admitted to establish that real property is community property even though title has been acquired under a deed executed in a form that ordinarily creates in the

47 United States v. Pierotti, 154 F.2d 758 (9th Cir. 1946).

48 Tomaier v. Tomaier, 23 Cal. 2d 754, 146 P.2d 905 (1944); 32 CALIF. L. Rev. 182 (1944); 17 So. CaIrr. L. REv. 401 (1944).

49 Ibid.

50 Supra note 47.

51 Supra note 48 at 757,146 P.2d at 906. A statutory amendment providing that community property placed in joint tenancy be treated as coinmunity property for tax purposes, would conform state to federal law and eliminate the need to prove, taxwise, whether it is or is not true joint tenancy. The three-fourth exemptions would be ended, together with all the problems they engender. 
grantee a common law estate with incidents unlike those under the law of community property."

In the Pierotti case a widow filed an estate tax return listing property owned by the spouses in joint tenancy. She stated that it was really community property pursuant to a specific agreenient and, therefore, excluded one-half as her community interest. The Commissioner included the entire property in the gross estate. The widow paid the tax and sued for refund. The district court decided in favor of the widow. On appeal the court of appeals stated that the evidence presented by the widow was sufficient to establish that the property was in fact community.

It appears that these cases hold the door open to variation of a written instrument of conveyance by oral testimony. Such variation may be achieved not only by the parties to the joint tenancy but also by anyone else. In Hulse v. Lawson, ${ }^{52}$ an earlier decision, a creditor of the deceased husband claimed that property standing in the names of the spouses as joint tenants was actually community property. In spite of the contrary contention of the widow, the court held that the property was community in character and therefore subject to the husband's debts. If a creditor could so argue successfully, there would appear to be no objection to a like contention by the Commissioner of Internal Revenue, the Controller of the State of California or anyone with an interest in the matter. Further, anyone may make this claim at any time, even after both joint tenants have died and there is 'no one to gainsay him. An unscrupulous claimant can also allege oral agreements which the co-tenants never made or had subsequently altered.

We may advance a step further through the open door. If oral agreements can be used to change joint tenancy back into community property, could they not be also employed to transmute joint tenancy into tenancy in common or a partnership or what-have-you? No form of title may, finally, be acceptable on its face. It is to be hoped that in the course of time, the scepticism of the courts inay be heightened by the ease with which a written instrument may now be varied and by the presence of the temptation to fabricate. Certainly the courts should scrutinize all oral agreements with great care.

Turning from contemplation of legal theory to the practicabilities of practice, we might well consider the words of a leader among federal tax experts, Mr. Alva C. Baird. In commenting on the Pierotti decision he stated," "We know that a revenue agent should scrutinize very carefully any attempt on the part of taxpayers to gain a tax advantage by contending that facts are other than what the written record shows [joint tenancy] and we know from practical experience that all revenue agents will look with suspicion on every attempt to estabhsh property as community property which is held as a matter of record as joint tenancy. This suspicion will not be allayed in any way by any proceeding in court which treats the property as though it were joint tenancy. Therefore, in any case where there is

52212 Cal. 614, 299 Pac. 525 (1931).

53 Title Insurance and Trust Company of Los Angeles, Panel Discussion 33 (1951). 
doubt about the sufficiency of the evidence, the property should be subjected to probate administration. If that is done and the Probate Court administers the property as though it were community property, no difficulty should be encountered with the Internal Revenue Department."

The acceptance of an oral agreenrent nray produce an entirely different disposition of the property than that contemplated by John and Mary. Under Sections 228 and 229 of the Probate Code of California it makes quite a difference whether property is separate or community. If both John and Mary die without issue or a will, and the property is proved to be community, one-half goes to relatives of John and one-half to those of Mary. If the evidence indicates that it had been John's separate property (and he as usual died first) it will all go ultimately to John's relatives and those of Mary will get nothing. If it had been Mary's separate property and she dies first, her relatives get the entire property. It is a safe assumption that neither John nor Mary ordinarily will draw a will. Hence these sections become operative and relatives that neither spouse favored nuy receive the estate or half thereof. ${ }^{54}$ The temptation is presented to such relatives to claim that the property is of whatever character would benefit them. Under the Tomaier and Pierotti cases such claims would appear to be admissible though both spouses are dead.

Of course, the establishment of the character of the property must be acconplished before the death of either Mary or John. They must decide how they want the property held while both are alive. The quandry of the joint tenants is evident. Conveyances which by their very nature throw the conveyees upon the horns of a dilemma should not be made without careful consideration by one well versed in the consequences-an attorney. Yet thousands of joint tenancies have been and are created without the slightest attention to or knowledge of their legal effect. The reason for such cavalier disregard is simply that people enter joint tenancy in order to avoid legal expense. If they consult counsel before so doing, they destroy the very advantage they seek.

Assuming that it is shown that the parties never intended to create a true joint tenancy and that they never meant to surrender the community status an interesting question arises: Can the surviving joint tenant assert his right to community property and still exercise the joint tenancy right of survivorship? A corollary query is: If the property is community property is it not includible in the probate estate? Under Section 682 of the Civil Code it appears that it cannot be both community and joint tenancy at one and the same tine. That section sets forth the various types of conveyances cognizable under California law. "Community property with the right of survivorship attached" is not one of then. This is the consequence which was foreseen and decried by Mr. Justice Preston in Siberell v. Siberell: ${ }^{55}$ "It would be manifestly inequitable and a subversion of the rights

54 In addition, these distant relatives will ordinarily be taxed at much higher rates than the normal objects of the decedent's bounty. CAL. REv. \& TAX CODE $\S 13310$.

55 Supra note 43 at 773,7 P.2d at 1005 . 
of both husband and wife to have them in good faith enter into a valid engagement of this character and, following the demise of either, to have a contention made that his or her share in the property was held for the community, thus brimging into operation the law of descent, administration, rights of creditors, and other conplications which would defeat the right of survivorship, the chief incident of the law of joint tenancy."

Logic, too, would require that one who eschews joint tenancy must also forego its principal and characteristic incident, the right of survivorship, and not attempt to engraft that right on community property. Mr. Justice Traynor has stated in Tomaier v. Tomaier: " "If the evidence establishes that the property is held as community property, however, it cannot also be held in joint tenancy, for certain incidents of the latter would be inconsistent with incidents of community property." Conspicuous and foremost among such "incidents" would be the right of survivorship. In the Pierotti case, the Commissioner contended that the utilization of a joint tenancy termination proceeding required that the property be treated as a true joint tenancy and not as community property as claimed by the taxpayer. The court held: ${ }^{57}$ "That proceedings under this section [Section 1170, Probate Code-proceeding to establish the fact of death-the joint tenancy "termination" section] are not to adjudicate conclusively the validity of the rights asserted." The court thereby restates a well established doctrine. ${ }^{58}$ However, is not this proceeding commenced in order that the right of survivorship, the chief incident of true joint tenancy, can be exercised? ${ }^{59}$ Such being the case, is an " 1170 proceeding" a proper method to dispose of community property? It can well be argued that, while "the validity of the rights asserted" are not conclusively adjudicated in an " 1170 proceeding," its commencement signals the use of the basic element of joint tenancy, the right of survivorship, requiring that the property be treated thenceforth as joint tenancy and not as community property.

It would appear that the court, in the Pierotti case, was sound insofar as its decision went. The commencement of an "1170 proceeding" does simply establish the death of the joint tenant. It does not transform community property into separate property, nor affect the character of the rights therein. If, however, community property exists, it belongs in a probate inventory, and an " 1170 proceeding" would be unnecessary. As part of the probate estate, it becomes subject to probate fees as well as administration expenses, all of which the decedent had sought to avoid by creating

56 Supre note 48 at 758,146 P.2d at 907.

57 Supra note 47 at 762 .

58 Hansen v. Union Savings Bank, 148 Cal. 157, 160, 82 Pac. 768, 769 (1905): "The decree in the proceeding [under what is now CAL. PROB. CODE \$ 1170] merely determines that, if the party petitioning has any asserted right or title accruing on the death of another person, such asserted right or title has accrued." In other words, all the $\S 1170$ proceeding does is clear the way for the exercise of the right of survivorship if there is such right. However, if it is not true joint tenancy but community property it is believed that such right does not exist and the property can only be transferred through probate.

59 Horn Estate, 102 Cal. App. 2d 635, 639, 228 P.2d 99, 101 (1951), "The distinguishing incident of a joint tenancy is a right of survivorship." 
the joint tenancy in the first place. It is also subject to disposition in accordance with the decedent's will, which may provide for a wholly different distribution than that planned by the decedent when he conveyed into joint tenancy. If there is no will, the decedent having relied on distribution by survivorship, the property may still be distributed to the widow on the basis of intestasy, ${ }^{, 0}$ but probate fees and expenses are nevertheless payable.

The layman joint tenant who may have happened upon this article has probably been wondering about the necessity for a proceeding to "terminate" the joint tenancy. He had been told that no court action was ever necessary. But, contrary to popular belief, some kind of a court proceeding must be commenced where the value of the entire joint tenancy property exceeds the statutory exemptions of the survivor. If John dies first, Mary's state inheritance tax exemption is $\$ 96,000$. This amount is the total of the specific exemption of $\$ 24,000^{61}$ and a marital exemption of up to one-half of all the separate property she takes, ${ }^{62}$ which amounts to another $\$ 24,000$, in addition to a $50 \%$ deduction for her contribution if new community earnings paid for the property. Were she to take $\$ 96,001$, one-half would be deducted as contribution, leaving $\$ 48,000.50$. Deducting the marital exemption leaves $\$ 24,000.25$. After the specific exemption of $\$ 24,000$, twentyfive cents remains to be taxed. If Mary dies first, John's exemption is $\$ 20$,000 , composed of $\$ 10,000$ contribution, $\$ 5000$ specific exemption ${ }^{63}$ and $\$ 5000$ marital exemption, computed as is Mary's. We have assumed that the joint tenancy property is separate, not community, in order to avoid a repetition of the complications discussed previously when community and jomt tenancy attempt to dwell in the same property. However, if the property is proved to be community property, the total exemption and exclusion, when Mary survives, is $\$ 48,000.64$ If John survives, and proof of community status is furnished, there is no inheritance tax, ${ }^{65}$ although the state does receive part of the federal estate tax if any is payable. If a minor child is the surviving joint tenant, the exemption is $\$ 12,000$ and if an adult child it is $\$ 5000 .^{60} \mathrm{~A}$ brother or a sister has a $\$ 2000$ exemption..$^{07} \mathrm{~A}$ stranger in blood has only a $\$ 50$ exemption. ${ }^{68}$ Assuming that John died leaving everything in joint tenancy and that the total estate, after funeral and last illness expenses, is $\$ 100,000$, Mary must pay a tax on $\$ 1000$.

The method of assessing inheritance taxes explains why Mary must commence a court proceeding. The superior court must make an order fixing the tax due, whether the property of the decedent is held in joint tenancy or as community subject to probate. The court acts on the basis of a report

60 Car. Prob. Code $\$ 201$.

01 CaI. Rev. \& TAX Code $\$ 13801$.

62 Car. Rev. \& Tax Code $\$ 13805$.

63 Car. Rev. \& Tax Code \$ 13801.

64 CAL. Rev. \& TAX CODE $\$ 13551$. With half of the community excluded, $\$ 24,000$, and the specific exemption of the remaining $\$ 24,000$, we reach the total of $\$ 48,000$.

65 Car. ReV. \& Tax CODE $\$ 13553$.

68 CaL. Rev. \& TAX CODE $\$ 13801$.

67 CaI. Rev. \& Tax Code $\$ 13802$.

68 Cal. Rev. \& Tax Code $\$ 13804$. 
by a State Inheritance Tax Appraiser, an officer appointed by the court. In order that the court will have jurisdiction to issue the appointing order, there must be a proceeding filed in that court. Such a proceeding is one under Section 1170. The surviving joint tenant cannot accomplish a major purpose of all laymen. Conveyance into joint tenancy does not avoid attorney's fees.

Pursuant to Sections 14307-14309 of the Revenue and Taxation Code an Appraiser can be appointed, appraisement made and a certificate releasing the inheritance tax lien issued without any court proceeding. But the sections according this relief afford no consolation to the survivor whose property has a total value in excess of the exemptions. These provisions were designed for and are specifically stated to apply no-tax cases only.

For two short periods in California history the "1170 proceeding" was mandatory whether a tax was due or not. The second period ended on March 25, 1952. The word "may" which had been replaced with "must" by the 1951 Legislature has been reinserted. ${ }^{69}$ That change restored to nontaxable survivors the advantage of the establishment of title in the survivor by "affidavit and certificate of death." Title, as has been stated, vested in each joint tenant when the joint tenancy was created, subject only to defeasement by death. In actuality, the affidavit serves two purposes: it proves to the title company's satisfaction that one joint tenant has died and it constitutes a record of such death which can be filed with the County Recorder.

We have already discussed the attempt to pass commumity property by right of survivorship and need not review that involved subject here. However, we should note that there are numerous lawyers who contend that an affidavit and certificate of death are not enough, even though no tax is due. These attorneys hold that a court decision under Section 1170 is the only proper way to establish death. We do not believe that the arguments on both sides need be aired in this article, although it should be noted that in northern California most attorneys began a court proceeding in every joint tenancy until the last amendinent to Section 1170 went into effect. ${ }^{70}$ All that need be said here is that another claimed advantage of jomt tenancy, avoidance of a proceeding, does not exist if a tax is due, while some doubt exists as to the propriety of omitting such proceedings even when no tax is owed.

Up to this point we have dealt with the consequences of the death of one joint. tenant. Advancing another step and contemplating the tax incidents of the death of the second joint tenant produces even less cheerful news for John and Mary. If John dies first, one-half of the property is taxed at that time. Upon the death of Mary, the entire property is taxed. In other words, the same property is taxed one and one-half times in one generation. The

69 By Act of Special Session of the Legislature, Cal. Stats. First Ex. Session 1952, c. 3 \& 1 . The previous compulsory period was 1931 to 1933 , Cal. Stats. 1931, c. 887 and Cal. Stats. 1933, c. 152.

to The amendment removed the mandatory word "must." 
possibility of one-fourth less federal tax on the basis of the three-quarter exemption theory depends on so many doubtful factors that we may disregard it. Even granting that all the hurdles in the path of its establishment were cleared, we are still left with the same property taxed a minimum of one and one-fourth times in the same generation. If Mary dies first, onefourth is taxed statewise, if new community in origin. Federally, we have previously concluded that one-half is taxable. Upon John's subsequent death, the entire property is taxed. Hence, when the deaths are juxtaposed we will still have the same property taxed federally one and one-half times and statewise one and one-quarter times in one generation.

Had John and Mary consulted an attorney, a substantial part of the tax could have been saved. Instead of joint tenancy, a will could have been prepared wherein a trust for Mary (or for John, if he survived his wife) would give her an income for life with remainder over for children or other relatives. At the death of John, the value of Mary's life estate would be taxed to her after an exclusion of one-half the property as her community interest. The balance after deduction of the life estate would be taxed to the remaindermen. Therefore the tax on the one-half remaining after the community exclusion would be spread between two or more persons (Mary and at least one remainderman) with a corresponding decrease in the tax rate. Upon Mary's death, her original one-half community interest is taxed, nothing more. In short, the property would be taxed once in each generation and inasmuch as the estate would be divided among several persons, the total tax paid would be less. The saving in tax would pay the attorney's fee many times over.

Frequently those who are intent on placing all their property in joint tenancy overlook items such as household furniture, farm equipment, and livestock. As a result, these assets must go through the probate court and be distributed according to the will of the decedent, or more often, as directed by the law of intestacy, since the decedent, believing he has disposed of everything by joint tenancy, rarely executes a will. The expenses of this probate often exceed the assets. This means, of course, that insofar as the probate assets are concerned, there will be no tax. However, the joint tenancy property may be greater than the exemptions. It would be expected that any excess of the expenses over the probate assets would reduce the amount of the taxable joint tenancy, but unfortunately that excess cannot be deducted. It is simply lost. ${ }^{71}$ This disadvantage of joint tenancy is minor compared with others previously mentioned and to be discussed.

In sum, if John intended to have his community cake and also eat it by using the joint tenancy survivorship primciple, he may subject the property to the expense of a probate and cause its distribution by the residue clause of his will to someone other than Mary. That person will have a considerably smaller tax exemption than Mary and will in all likelihood become subject to state inheritance tax, at the least. Hence even the estate we have been considering as "small" may be subjected to legal expense, tax, and

71 INT. REv. CODE $\S 812$ (b) ; U.S. TREAS. REg. 105, § 81.29 (1943). 
maldistribution. We have mentioned proceedings pursuant to Section 1170 of the Probate Code to "terminate" joint tenancy. If Mary, after his death, insists on terminating the "joint tenancy" by exercising the right of survivorship, she may thereafter pass title with a cloud. Of course, neither John nor any other joint tenant gives this matter any thought, knowing nothing about such "legal folderol."

Briefly, no estate or inheritance tax is saved by placing property in joint tenancy. On the contrary, it may increase such taxes. If John and Mary want to save some death taxes, they should leave their property in its cominunity status and execute a will disposing of their assets to the ultimate beneficieries beyond their generation.

Of course, the small estate is not concerned with death taxes as long as it remains small, but it may not escape administration expense if it is proved to be coinmunity property. Further, it may not all go to the intended recipient, the surviving joint tenant, if a creditor, taxing authorities, a warring wife or anyone who may have an interest in the matter proves it to be community property.

\section{Income Taxes}

At one time a definite advantage accrued to those who owned separate property and who placed it in joint tenancy. The mcome therefrom was divisible between the husband and wife as joint tenants, thereby reducing the tax due, the tax rates being based on the level or amount of income each received. That advantage is no longer limited to joint tenancy. The Revenue Act of 1948 now permits all income, be it received by spouses in joint tenancy or by the husband or wife alone, to be split equally. ${ }^{72}$ Hence, one gains nothing in this respect from jomt tenancy that would not be otherwise available.

A most serious disadvantage, income-tax-wise, is inherent in joint tenancy. It stems from the language of Section 113(a) (5) of the Internal Revenue Act. This is the "basis" section-a source of woe to the joint tenant. Knowledge of this provision is almost universally lacking among the joint tenancy aspirants. Rarely, if ever, do they consult a counsel, for to do so would cause an expenditure that joint tenancy is supposed to avoid. As a result the basis problem, a major factor to be carefully considered by a legally qualified person, is ignored.

A typical case will illumine Section 113(a)(5). In the year 1930 John Brown places property worth $\$ 10,000$ in joint tenancy with his wife Mary. John dies in 1950. In the intervening two decades the property has increased in value and is worth $\$ 50,000$ in the year of death. Such an advance in price is not unusual. The writer has interviewed hundreds of survivors whose properties have quadrupled and quintupled in half a score of years. Mary camiot handle the property alone. She sells it in the year of death for $\$ 50$,000. Mary is then confronted for the first time with Section 113(a)(5). It is therein provided that only the basis of inherited property is changed

${ }^{79}$ INT. REv. CODE \& 12 (d). 
by death. Since joint tenancy property does not pass by inheritance, its basis is fixed at the date of conveyance into joint tenancy and is thereafter unalterable. The death of John in 1950 has no effect on the basis of the joint tenancy property. Mary must, therefore, pay a capital gains tax on the difference between $\$ 10,000$ and $\$ 50,000$. As the property has been owned by Mary and John for more than six months, one-half of the difference is taxed at $26 \%$ as "Iong term" capital gains, producing a tax of $\$ 5200$. If John had resisted the well meant suggestions of the real estate salesmen or escrow clerk and had held the property as commumity, Section 113(a)(5) would have permitted the basis of the property to be elevated to $\$ 50,000$ at his death. Such basis would be the same as the selling price, and there would be no capital gains and no capital gains tax. The saving would be the entire $\operatorname{tax}, \$ 5200$. In addition, no gift tax would be incurred and the one and onehalf estate and one and one-fourth inheritance tax payable in one generation would be avoided.

Furthermore, John and Mary may have been deducting a certain amount of depreciation annually from the income of the property. The total of such depreciation must be deducted from the basis established at the inception of the joint tenancy, which is the donor's basis if the conveyance was without consideration. If the property has been held by John and Mary for a number of years, the depreciation which has been charged off may reduce the basis to zero. As a result the capital gains would be the entire selling price. On the other hand, community property is not decimated by whatever depreciation is taken. Instead, the basis of community property is "stepped up" to the value at date of death and can be depreciated a second time. ${ }^{73}$

Consider the case of a brother-sister joint tenancy. If property worth $\$ 15,000$ in 1941 went the way of most property, its value may very well have increased five-fold to $\$ 75,000$ by 1952 . If, in 1952, a joint tenant dies, no change occurs in the basis to conform it to value at date of death-it remains $\$ 15,000$. Hence, if a sale subsequently occurs, the capital gains tax is $26 \%$ of one-half of the gain, or $\$ 7800$.

Assume that the brother died in 1952, that the property was held by him in his name only, that it was willed by him to his sister and that the property had also accreted to $\$ 75,000$. In such case, the base is raised as of date of death to $\$ 75,000$ and the capital gains tax for a sale at $\$ 75,000$ is zero ( $\$ 75,000$ selling price minus $\$ 75,000$ new basis). The degree of relationship is irrelevant. Under these facts, which pose a not unusual situation, $\$ 7800$ in capital gains tax alone could be saved by avoiding joint tenancy. Remember also that if the property were in the brother's name only and the sister died there would be no need to burrow into the past to seek long discarded proof that the brother had contributed, as would be necessary had the property been placed in joint tenancy.

The problem becomes aggravated as the value of the property increases. Where property held by uncle and nephew jumps from $\$ 10,000$ at date of

${ }^{73}$ INT. REv. CODE $\$ 113$ (a) (5). 
joint tenancy to $\$ 100,000$ at death of a joint tenant, where sale is made just after death and more than six months have elapsed since the joint tenancy was established, a tax of $\$ 11,700$ is needlessly incurred. If less than six months have intervened, the tax zooms to $\$ 23,400$.

It is also true that property held as community property in the name of one or the other of the spouses ${ }^{i 4}$ or in the name of a person other than a spouse, must pass through probate, thereby incurring the probate expenses so dreaded by the joint tenancy advocates. ${ }^{75}$ A comparison of income taxes, not to mention gift and possibly greater death taxes, brought about by joint tenancy with the probate expenses saved by joint tenancy quickly reveals that the joint tenant is penny wise and pound foolish. The husband-wife example involved property valued at $\$ 50,000$. Assuming that that is the entire estate and the husband dies first, probate expenses would approximate $\$ 1,500$ if the widow waives, as she should, her commission as executrix. $^{78}$ The saving of a capital gains tax of $\$ 5,200$ far outweighs the probate expense incurred. In the brother-sister example, there would be a capital gains tax of $\$ 7,800$, while probate fees would be approximately $\$ 2,000$, again assuming that the executrix waives fee, and no tax would be due. If she does not waive her commissions, the total probate expense would be considerably less than the capital gains tax alone, in addition to which gift and death taxes must be considered. In the uncle-nephew example, the probate expenses would be approximately $\$ 4,500$, assuming an executor's commission is paid, as agaimst a saving of $\$ 11,700$ of capital gains tax by probate. From the viewpoint of the person who foresees the sale which usually follows a death, joint tenancy under these circumstances simply forces an unnecessary gift to the public treasury.

Of course, were prices to cease advancing and values to commence falling, the disadvantage of joint tenancy caused by Section 113(a)(5) would be obviated. The possibility of such a trend seems quite distant at the moment and, in any case, planning an estate on the premise that the future is dim is not sensible. Our economic history will indicate, the writer believes, that periods of recession and depression are relatively much shorter than our periods of expansion, prosperity and upward moving prices.

Here, then, we see again how joint tenancy invites unnecessary taxation.

7£ If in wife's name only, CAL. CIv. CODE $\$ 164$ would raise a presumption that it is her separate property. Hence if the husband dies first, no estate or inheritance tax would be due if the question of contemplation of death is not raised. Here, however, we are assuming that it can be proved that the property remains community even though in wife's name.

75 The basic and largest items of expense are the commissions and fees of executor and attorney. CAL. Prob. CODE $\$ \S 901$ and 910 fix identical rates of compensation for both lawyer and executor, as follows: $7 \%$ of the first $\$ 1000$ of accountable estate, $4 \%$ of the next $\$ 9000$, $3 \%$ of the next $\$ 10,000,2 \%$ of the next $\$ 30,000$ and $1 \%$ of all above $\$ 50,000$.

76 If the wife takes her commission as executrix it is income to her taxable at rates exceeding the estate tax rates which would be applicable if she took such commission as part of the estate. All this assumes the usual case in which the wife is appointed executrix and all or a large part of the estate is willed to her.

75 The ordinary case would be a sale shortly after the death, hence, in probate, the base would have risen to approximately the selling price with the result that the entire capital gains $\operatorname{tax}$ of $\$ 7800$ would be avoided. 
Of all the disadvantages from which joint tenancy suffers, the capital gains tax is the most crippling. The joint tenancy proponent might clamor for a change in Section 113 (a) (5) to accord that form of conveyance the benefits given other types of property holdings. Setting aside the legal obstacles inherent in joint tenancy, the writer is convinced that the possibility that such legislation can be enacted is extremely remote in view of the great need for all sources of revenue in these perilous times.

\section{Estate Planning}

Up to this point we have been discussing taxes and their causation by joint tenancy. In order to present the entire picture we should discuss more fully other consequences stemming from this form of conveyance which may be even more damaging to the joint tenants than the incidence of taxes.

The inflexibility of true joint tenancy is a serious drawback. Once in joint tenancy, one-half of the property passes out of the control of the original owner. He can only recover such property with the consent of the other co-tenant or by the latter's death. If the new joint tenant conveys away his interest in the property prior to death, the original owner loses his right of survivorship as well as half of the property. The joint tenancy is thereby destroyed ${ }^{78}$ Further, the new owner and the original co-tenant now hold their interests as tenants in common. It then behooves the original owner to execute a will immediately wherein he disposes of his moiety, else it will pass according to the laws of intestacy and not necessarily in accordance with his wishes.

Another disadvantage of joint tenancy is sharply underlined when doinestic peace is shattered and a marriage founders. Then it is too late for John to attempt to recover property he placed in joint tenancy. Mary's right to an equal undivided interest cannot be taken away. She inay dispose of that interest without John's consent and to whomever she pleases, pocketing the proceeds of the transfer. ${ }^{79}$ In fact, Mary could have disposed of her interest at any time. Upon such a transfer, the joint tenancy is destroyed, and John has lost all rights in one-half of the property. While we all hope for domestic tranquility, we must take cognizance of the large number of cases where it is absent and where joint tenancy plays havoc with the plans of the spouses.

Knowing how frequently these events do occur, attorneys should counsel their clients not to expect joint tenancy to discharge the function of a will. If testamentary disposition is the primary purpose of the prospective joint tenant, he inust be unequivocally advised that a will is a superior tool and has been so for many centuries.

If separate property is left in the name of the original owner, or commumity property is in the name of the husband, or of both spouses "as hus-

78 Gwin v. Camp, 25 Cal. App. 2d 10, 76 P.2d 160 (1938). For a discussion of the effect of a levy of execution on a joint tenancy interest, see Van Antwerp v. Horan, 390 Ill. 449, 61 N.E.2d 358, 161 A.L.R. 1133 (1945); Ziegler v. Bonnell, supra note 5.

70 Delanoy v. Delanoy, 216 Cal. 23, 13 P.2d 513 (1932). 
band and wife," each spouse can freely dispose of his own property or his interest in the community property by will..$^{80}$ The husband can give his wife merely a life estate im his property or share of the community, and leave a remainder to his children, thereby reducing taxes as previously described. A husband can dispose of his wife's interest in the community as well as his own, if she consents by written election prior to the husband's death, or prior to distribution. Such power of disposition enables the spouses to make a plan for their children or other relatives. The plan can be revoked or revised to fit altered circumstances. However, where all property is placed in joint tenancy, estate planning is at an end. Once in true joint tenancy, the die is cast.

The contingencies raised by life's uncertainties cannot be resolved by joint tenancy. For example, where property is in joint tenancy and the husband dies first, all of it goes to the widow. If she remarries, she will probably place all the property in joint tenancy with her new husband. Upon her death before her new husband, the latter will be the sole owner of all, and any children of the first marriage will come away empty handed. Again, suppose John and Mary have no children but are fond of John's meces and nephews. Mary's relatives are distant cousins whom she has rarely seen. If John dies first, it all goes to Mary. Upon her death without remarrying and without a will, Sections 228 and 229 of the Probate Code control the disposition. If it had been John's separate property originally, his close relatives, if any, take it all. If it had been Mary's separate property in the beginning, her relatives would take everything. If the property was originally community, the husband's nephews and nieces would get half. Hence, although John and Mary really intended that the nephews and nieces take all, only if the property had been John's separate property would their wishes be fully accomplished. Their intent could have been easily implemented by a simple joint will or by separate wills.

Again, there is the possibility that the joint tenancy would be destroyed by a conveyance of one-half by one of the joint tenants, thus preventing the original owner from recovering his property on the death of the conveyor. A whole plan of distribution which may have based on the right of survivorship will then go by the board.

The joint tenant who acquires an interest in property has been known to be dizzied by her new affluence. Numerous debts may be incurred by her. Anxious creditors can levy on and sell her undivided half interest in the joint tenancy, thereby severing the joint estate. ${ }^{81}$ When John and later Mary both pass from this mortal coil, if the property had originally been John's separate estate, it will vest in his heirs. But under the far-reaching Tomaier decision, a third party may contend that there was an oral agreement that the property was community, thus depriving John's heirs of half and subjecting the other half to Mary's creditors. The door is open for fabricators to say what they will and prove what they can.

80 Car. Crv. Code $\$ 164$.

81 Ziegler v. Bonnell, supra note 5. 
Note that the Tomaier rule may be invoked by creditors who prove joint tenancy to be actually community property. Hence an attempt to avoid one's debts by use of joint tenancy may well fail. ${ }^{82}$ So, too, the Bureau of Internal Revenue might prove community property where the widow claims half of the joint tenancy to be her separate property and demands a marital deduction in the other half. If the court agrees with the Bureau (or the state) the entire joint tenancy will be treated as community property, and only one-half will be excluded. Of course, the widow's claim can only be made if joint tenancy was created between 1927 and 1948 , but not in $1942^{83}$

It sometimes happens that the decedent-to-be keeps assets such as real property in his name only, but places all liquid assets such as cash and stock in joint tenancy, in order to provide the beneficiary with funds immediately upon his death. Such disposition may cripple the whole program of distribution, inasmuch as the remaining estate property may be insufficient to pay taxes and administration expenses without selling the real property. The executor cannot make use of the joint tenancy money as it is not subject to his administration. As previously stated, the excess expenses cannot be deducted from the joint tenancy property and so reduce the total taxable estate. ${ }^{84,85}$

\section{Joint Bank Accounts}

The joint bank account is a very common form of joint tenancy. The ease with which a joint bank account may be made available to the surviving joint tenant is a definite advantage. The survivor appears at the office of the County Treasurer and requests a release of the account. The County Treasurer puts a few questions and, if obviously no tax is due, he issues the release forthwith. However, if he is at all doubtful as to the taxability of the account he will refer the matter to the Inheritance Tax Department. There the survivor will complete a short form describing the assets of the decedent and a Department attorney will ascertain whether the devolution of such assets to the heirs of the decedent and to the surviving joint tenant or tenants produces a tax. If not, a release is issued. If the estate is taxable and the bank account is the only asset of the decedent, a computation of the tax is furnished the survivor. When he pays the tax, and whatever interest may be due to the County Treasurer, a release can be secured which the depository will honor, and the account will be turned over to the survivor.

If a true joint tenancy was intended by the depositor, the rights of the co-tenants are the same as joint tenants in any other kind of property. Gift tax, however, will not accrue until and unless the nondepositor withdraws his interest. The reason for such rule is the continued exercise of dominion over the account by the depositor.

Under Section 15A of the Califorma Banking Act (now Section 852,

82 Hulse v. Lawson, supra note 52.

83 INr. Rev. Cone $\S 812$ (e) (2) (c) (i) and (ii).

84-85 See text preceeding note 7I, supra. 
Financial Code), two presumptions arose with respect to the joint bank account: first, that a deposit in joint tenancy was the property of the joint tenants, and second, that the owner-depositor intended to vest title in the survivor. The first presumption was rebuttable, the second was conclusive. A recent case, Paterson v. Comastri, illuminates the application of these presumptions. The decedent there created joint bank accounts with her sister but before death transferred all the funds to accounts held jointly by herself and her husband. As the presumption that each tenant had an undivided interest was rebuttable, the court permitted the introduction of parol evidence to overcome such presumption. So overcome, the depositor was permitted to withdraw the entire account. Hence, the second presumption, conclusive though it was, had nothing upon which to operate as there were no funds left in the account to which the sister could assert her undeniable right of survivorship.

Section 15A was superseded by Section 852 of the Banking Code, effective in 1949. That code in turn has been succeeded by the Financial Code containing the same section. Section 852 of the Financial Code does not term the inaking of the deposit "conclusive evidence" of the intention of the depositors to vest title to the deposit in the survivor. As a result, even after death the surviving joint tenant may find the joint tenancy bank account subject to attack by a third person.

It will be perceived that here too, as under the Tomaier rule, the door is open for anyone to clain that a true joint tenancy was not intended despite a written joint tenancy contract. The effect of the establishment of such a clain is more far-reaching than the establishment of commumity property over joint tenancy, for here the entire joint tenancy may be recouped by the creator of the joint bank account and otherwise disposed of without so much as notice to the noncontributor. In short, a noncontributing joint tenant in a bank account can not be sure of any benefit from such tenancy even though the contributor dies without having made off with the funds.

There is patently no saving of estate or inheritance tax by creation of joint bank accounts. Also, gift tax may accrue upon withdrawal of funds in excess of the exeinptions.

\section{Conclusion and Proposal}

We may conclude that the advantages of joint tenancy are confined to the small estates. In such estates, the advantages of avoiding probate delay and expense, as well as attorneys' fees, are not to be minimized. They are real and substantial to the person whose property consists of an average house, a few bonds, a car, and a marginal bank account. His attention is not to be diverted from these advantages by the fact that a capital gains tax will be payable after his death when, and if, his widow sells the house. Quite possibly she will not sell. Nor is he overly concerned about the lack of testamentary disposition. His wife is the chief object of his bounty and she

8039 A.C. 68,244 P.2d 902 (1952). 
is his co-tenant. Chance that his spouse might make off with her interest seems slight. His estate is too small to be subject to gift tax upon conveyance into joint tenancy. There will be no inheritance tax due at his death, and if his children are numerous enough, none will be due at the death of his wife. Hence, for a large segment of the population, joint tenancy is the solution to the problem of disposing of one's worldly goods. These people would, and should, oppose the abolition of joint tenancy.

As we ascend the economic ladder, all the perils which were nonexistent below become very real. John Brown's modest estate need only increase a little to be subject to gift taxes. Both at his death and the death of his widow, inheritance taxes are due, and both are imposed on the same property. The capital gains tax which seemed remote to the person in modest circumstances now looms large. Although probate would be avoided, his widow must retain and pay an attorney to begin a proceeding to determine the inheritance tax. If he would like to leave money or property to someone other than his wife, he can only do so through joint tenancy by joining such beneficiaries with his wife as joint tenants, an act binding him for the remainder of his days.

When we reach the not inconsiderable group whose assets after all deductions exceed the federal exemptions $(\$ 60,000)$, the advantages of joint tenancy dwindle into insigmificance. An attorney must still prepare the complex federal estate tax return (the famed Form 706), attend Bureau conferences, and prepare a proceeding to deterumine the state inheritance tax; he must expend so much effort and time on the estate as to require him to charge a fee for his services which may approach or exceed the probate fees, both statutory and extraordinary. The probate expenses, other than executor's commissions, which would in most instances be waived, may ultimately be no more than those incurred in clearing up his joint tenancy estate. The delays incident to a federal tax determination make the time consumed by probate seem like a weekend at the beach; hence the third advantage of joint tenancy, expedition, is gone. Against the once impelling advantages are now pitted the disadvantages of gift taxes and a capital gains tax that can be crushing. We can say with justification that joint tenancy should not be employed by people in this category unless taxes do not matter.

We cannot, of course, abolish joint tenancy for the large estate and retain it for the small estate. Nor can we categorically declare that if one has so much property and a good and true wife he should place his property in joint tenancy (subject always to the contingency of a capital gains tax), while if one has more he should not do so. Estates do not always remain small; ten or twenty years hence John Brown may very well have increased his holdings beyond the small estate stage, and all the joint tenancies which he will have created will be in vain, taxwise.

If, however, probate proceedings were made less expensive and less time-consuming by legislative action, the urge to create joint tenancies would be greatly diminished. The public is not enamored of joint tenancy 
per se, but only of its accoutrements. Vest "probate property" with the virtues ascribed to joint tenancy, and we will have solved the problem. This could be done by providing that where a probate estate is not subject to inheritance tax, it may be "set aside" to the beneficiary under the will or the heir at law without further procedure. The present statute permits an estate to be set aside only to a spouse or minor child if the whole estate in excess of liens is less than $\$ 2500 .{ }^{87}$ The proposal would not affect many persons other than the surviving spouse or minor children. A huge percentage of all joint tenancies are between husband and wife, and the bulk of the prospective cases for the foreshortened probate would be drawn from joint tenancy. ${ }^{88}$ Other than a spouse or minor child, no one has an inheritance tax exemption greater than $\$ 5,000$. Aside from the adult child $(\$ 5,000)$ the next highest exemption is $\$ 2,000$ (brother, sister, et al.) ${ }^{89}$ It would seem unfair to refuse to set aside a $\$ 2,000$ estate for a brother when under the present provisions a wife or child can acquire $\$ 2,500 .{ }^{.0}$ Once these exemptions are exceeded it becomes a tax case (as it would be even though in joint tenancy) and the proposed provisions would be inapplicable. Actually only a small number of additional cases other than spouse and child would be able to take advantage of the set-aside. The others would be taxable in any case and fall within the normal probate orbit.

A nominal filing fee should be charged. An attorney's services would be needed to draw the simple document to "set aside" and the statute should provide that the fee for such procedure be, say, $\$ 25$ minimum, or one-tenth of one per cent of the value of the property, whichever is greater. ${ }^{91}$ An appraiser's services would be required to determine the value. His fee is presently so low- $\$ 5$ for the first $\$ 5,000$ and one-tenth of one per cent for the next $\$ 495,000$ - as to be nominal in the small estate..$^{92}$ The valuation he furnishes would serve as the new basis, and the capital gains tax saved would be a hundred times more than his fee and that of the attorney. In addition, the valuation could serve, and has in the past, as an offering price if the widow desires to sell the property. Hence, in the $\$ 25,000$ estate, the total cost would be $\$ 50$, very little to pay for the many advantages of probate. When the estate grows beyond the limits of the set-aside provision, it would automatically fall into the regular categories now existing. In such cases, it has been pointed out that the probate expense may not be much greater than what must be incurred to complete a joint tenancy termination, and, most important, gift and capital gains taxes are saved. All parties

87 Cal. Prob. Code $\$ \$ 640-646$.

88 Conservatively, $85 \%$ of all joint tenancies, Ogden, supra note 2.

80 Supra notes 66-68.

90 Car. Prob. Code $\$ 640$.

81 If only a inodicum of the property held by husband and wife in joint tenancy were placed in a streamlined probate, attorneys would find the modest fee to be more than ample reward because of a great increase in the volume of their practice. Also, many persons will be setting foot in law offices for the first time in their lives-an excellent opportunity to remove lay suspicion of the profession.

82 Cal. Prob. Code $\S 609$. 
to such an arrangement are benefited. Finally, a will, with all its flexibility and versatility, could now be prepared and would be effective.

Such provisions would stop and reverse the widespread flight from probate and remove temptation from the paths of escrow clerks, notaries public, real estate salesman, and other laymen. No longer would John Brown need to inquire of them as to means of avoidance of probate-the "set aside" law would be so advantageous as to make the inquiry unnecessary. In addition, his estate would be able to secure legal counsel at a rate which any householder can afford.

The above solution to a vexing problem contains several ideas evolved by the writer after cogitating upon the many jomt tenancies he has examined, both in private practice and as attorney for the Inheritance Tax Department. However, the basic thought is merely an extension of a policy already incorporated in the law of California. Section 630 of the Probate Code now provides that a surviving spouse, children, issue of deceased children, parents, brothers or sisters, or a guardian of the estate of any minor or insane or incompetent person bearing such relationship to the decedent can all file a simple affidavit and collect any money or property of the decedent if his estate does not exceed $\$ 1,000$. Section 630.5 declares that where an estate of a decedent does not exceed $\$ 5,000$, an affidavit may be used by the surviving spouse to withdraw up to $\$ 500$ on deposit in the decedent's name. Sections 640 through 646 of the Probate Code are the solid basis on which this writer's proposal is built. These sections outline a probate in miniscule, a proceeding foreshortened so that a mimimum of delay and expense is incurred. Under these provisions a petition by the surviving spouse or minor child, listing the decedent's property and the encumbrances, will be granted and the estate set aside to the spouse or child if the net estate, after deduction of the encumbrances, does not exceed $\$ 2,500,{ }^{03}$ and if the assets of the spouse or child to whom the set-over is made, do not exceed $\$ 5,000 .{ }^{94}$ An inheritance tax appraiser is appointed by the court unless the entire estate consists of money, in which case none is appointed. ${ }^{05}$ As to notice to creditors, none other than the general notice of hearing on the petition is given. ${ }^{\circ 6}$

These sections of the Probate Code indicate that the legislature has already considered the problems of the small estate in probate and has resolved them in exactly the same inanner as here proposed, except that the present proposition widens the scope of the legislative solution and permits a treatment of all estates which are not subject to inheritance tax in substantially the same manner as estates presently within Sections 640 et al. An additional proviso that the statutory attorneys' fees be reduced, in notax cases only, will be one of the basic reasons for joint tenants to discard their old feudal friend and embrace probate. The increase in probate prac-

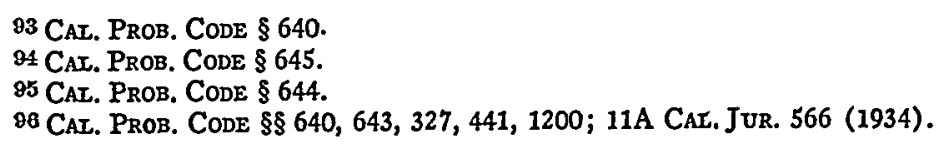


tice should compensate attorneys many times over for the fee reduction proposed.

Creditors need not fear this proposal. No outcry has been heard from creditors because of the present proceeding under Section 640, et seq. They do receive the general notice, ${ }^{97}$ and additional protection could be afforded them under the foregoing proposal by providing for a thirty- or sixty-day creditors' notice. This should be ample time for all creditors in this age of instantaneous communication. Be it noted that a creditor of a deceased joint tenant is entirely helpless and can recover nothing from the surviving joint tenant. Nearly nine-tenths of all conveyances between spouses, creditors should note, are into joint tenancy. ${ }^{98}$

Until the legislature makes a salutary improvement such as above proposed, joint tenancy will continue to attract vast numbers of fugitives from the probate court. What can be done in the interim to reduce joint tenancy holdings?

One of our most distinguished practitioners has suggested that "If the incident of survivorship is considered indispensable the substance of that incident may be preserved by the creation of joint life estates, with remainder to the survivor." ${ }^{99}$ However, such an estate would necessitate the expense of legal counsel which, judging by the huge numbers of joint tenants, a vast section of the public cannot or will not incur. It also fails to solve the basis problein. ${ }^{100}$

Another-leader at the Bar believes that a summary form of probate procedure would be a prerequisite to abolition of joint tenancy. ${ }^{101}$ It is hoped that he will see merit in the plan here proposed.

Beware, then, of joint tenancy, avoid it if the estate is more than the minimum of a honie, car, and small bank account. If the estate is minimal, some comfort is derived from joint tenancy but it must always be reinembered that a capital gains tax probably awaits the disposition of the assets by the survivor. Remember also that the transferor has nothing further to say as to property in joint tenancy unless he or she destroys such tenancy, and even then control is regained over only one-half.

This article has outlined advantages and disadvantages springing from joint tenancy. A proposal to remedy the situation has also been roughed out. Many have inveighed against joint tenancy. We have heard enough criticisni. It is hoped that now we will proceed to work out a sound solution to the problem, both taxwise and otherwise.

97 Ibid.

98 Ogden, supra note 2.

99 Walter L. Nossaman, 27 CarIF. Srate B. J. 21, 25 (1952). The paragraph continues, "This kind of an estate would preserve the one benefit of joint tenancy, namely, exclusion of the property from probate, and obviate some of the objections to it. And, what is more important, the creation of such an estate would involve a deliberate act, done under legal advice. The limitation of survivorship to remainder interests so created would take from certain lay groups the privilege they now enjoy, of inducing people to enter into arrangements which in most cases are disadvantageous, and in many cases disastrous. It is believed that no substantial public interest would be prejudiced by the discontinuance of that privilege."

100 Ivr. Rev. Code $\$ 113$ (a) (2) ; U.S. Treas. REg. 111, \$29.113(A) (2)(1) (1949).

101 Richard H. Forster, speech, Southwest Bar Association, April 24, 1952. 